\title{
Documentation of multiple species of marine fish trapped in Atlantic salmon sea-cages in Norway
}

\author{
Per Gunnar Fjelldal ${ }^{1, *}$, Monica F. Solberg ${ }^{2}$, Kevin A. Glover ${ }^{2,3}$, Ole Folkedal ${ }^{2}$, Jonatan Nilsson ${ }^{2}$, \\ Roderick Nigel Finn ${ }^{3}$ and Tom Johnny Hansen ${ }^{1}$ \\ ${ }^{1}$ Institute of Marine Research (IMR), Matre Aquaculture Research Station, 5984 Matredal, Norway \\ 2 Institute of Marine Research (IMR), PO Box 1870, Nordnes, 5817 Bergen, Norway \\ ${ }^{3}$ Institute of Biology, Bergen High Technology Centre, University of Bergen, Bergen, Norway
}

Received 4 April 2018 / Accepted 5 June 2018

Handling Editor: Costas Tsigenopoulos

\begin{abstract}
The production of salmonids in sea-cages has been developed for monoculture of the target species. However, we show here for the first time, that wild fish may enter sea-cages used for farming of Atlantic salmon (Salmo salar L.) in Norway, out-grow the mesh size, and thereafter become permanently trapped. Within seven different sea-cages located in western Norway, eight different species of wild fish were identified; European eel (Anguilla anguilla), sea trout (Salmo trutta L.), cod (Gadus morhua), haddock (Melanogrammus aeglefinus), saithe (Pollachius virens), pollack (Pollachius pollachius), hake (Merluccius merluccius) and whiting (Merlangius merlangus). In the two most extreme cases, a $5 \times 5 \times 7 \mathrm{~m}$ cage with 311 farmed salmon ( $903 \mathrm{~g}$ ) also contained 542 whiting ( $79 \mathrm{~g}), 77$ haddock $(43 \mathrm{~g})$, and $5 \mathrm{cod}(26 \mathrm{~g})$, and a $12 \times 12 \times 15 \mathrm{~m}$ cage with 1695 farmed salmon $(559 \mathrm{~g})$ also contained 1196 haddock $(35 \mathrm{~g}), 1115$ whiting $(31 \mathrm{~g}), 46 \mathrm{cod}(23 \mathrm{~g}), 23$ saithe $(48 \mathrm{~g}), 15$ pollock $(22 \mathrm{~g}), 5$ sea trout $(54 \mathrm{~g})$, and 2 hake $(29 \mathrm{~g})$. The present study thus demonstrates that aquaculture cages designed for monoculture may attract and effectively 'trap' wild fish. We did not investigate the frequency of this occurrence, and the ecological significance of these observations remains unclear. However, with the ever-increasing number of sea-cages used for global aquaculture, this is clearly a topic for further research.
\end{abstract}

Keywords: Ecology / life cycle / gadoids / fjord / coast / finfish mariculture / polyculture / environment / bycatch

\section{Introduction}

World aquaculture production is increasing, and within the marine environment, sea-cages that are open to the surrounding water masses represent the standard approach to production. In Norway, which is the world's largest producer of Atlantic salmon (Salmo salar L.), 3460 sea-cages were distributed among 535 localities along the coastline as of January 2016 (http://www.fiskeridir.no/fiskeridir/Akvakultur/ Statistikk-akvakultur/Biomassestatistikk). On a global scale, the number of sea-cages may well run into the tens of thousands or more.

A number of challenges linked with environmental sustainability of cage-based salmonid aquaculture have been reported, and of these, farmed escaped salmon that may display genetic interactions with wild conspecifics (Glover et al., 2017), and increased mortality of wild smolts via infection with the

*Corresponding author: pergf@imr.no parasitic salmon louse, Lepeophtheirus salmonis, rank as the two major challenges in Norway (Taranger et al., 2015; Forseth et al., 2017). However, another possible negative interaction, not yet studied in the Eastern Atlantic Ocean, where most of the production of farmed Atlantic salmon takes place, is that juvenile wild marine fish may enter and thereafter become trapped within sea-cages. Indeed, in Canada, the Fisheries and Oceans Canada's (DFO's) Conditions of License for finfish aquaculture require facility operators to maintain an incidental catch $\log$ (http://open. canada.ca/data/en/dataset/0bf04c4e-d2b0-41889053-08dc4a7a2b03). This database dates back to 2011, and demonstrates that a wide variety of wild fish species have been incidentally recovered from commercial cages in the Western Atlantic Ocean. Also in the Mediterranean Sea, Fernandez-Jover et al. (2009) found that several juvenile fish species settled at seacage fish farms, while Sanchez-Jerez et al. (2008) found that adult bluefish (Pomatomus saltatrix L.) can enter aquaculture sea-cages, and prey on the cultured fish.

Knowledge about the possible negative interactions between aquaculture and the natural environment is a 


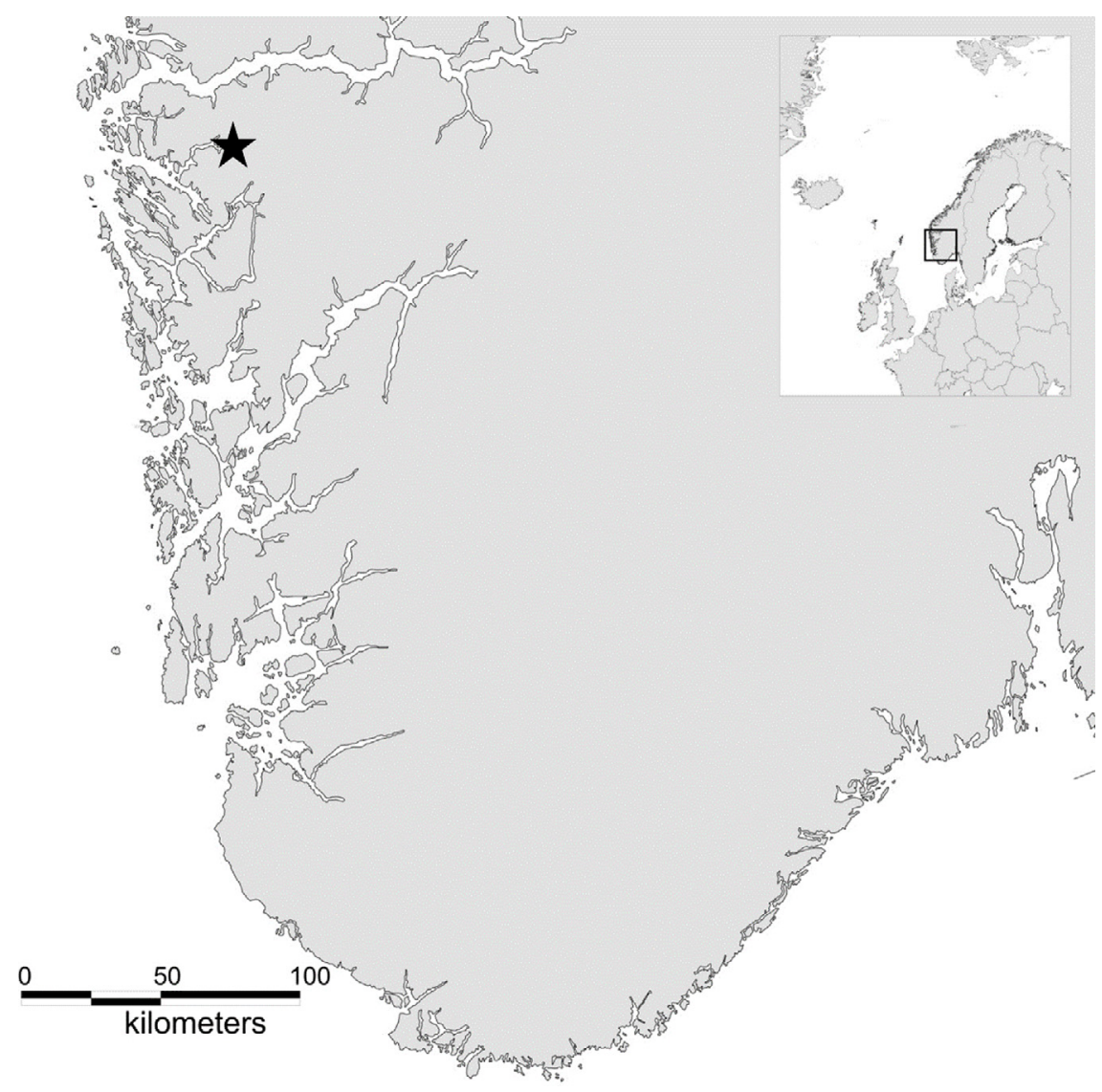

Fig. 1. Map showing the location of the aquaculture sites Smørdalen and Solheim, western Norway (black star) where the present wild fish were documented inside sea-cages stocked with farmed Atlantic salmon (Salmo salar L.). The sites are located $6000 \mathrm{~m}$ apart.

prerequisite for the development of sustainable production practices. To investigate if salmon sea-cages may attract and trap wild fish, we examined the total fish content of seven research sea-cages stocked with farmed salmon in western Norway. These cages were investigated with respect to the species observed, their abundance and size.

\section{Material and methods}

The Institute of Marine Research (IMR) in Norway operates two Atlantic salmon experimental farm sites in Masfjorden, on the west coast (Fig. 1). This is one of the major production areas for Norwegian aquaculture, and the experimental farms are situated in an area typical for commercial farms. While sampling experimental fish from some of the cages located on these farms, various wild marine fish were observed. Consequently, we quantified the total number of wild fish in seven of these sea-cages in order to identify the numbers and types of species trapped. The cages examined were located at the Smørdalen (cages 1-6) and Solheim (cage 7) marine farming facilities $\left(60^{\circ} \mathrm{N}, 5^{\circ} \mathrm{E}\right)$. The depth under the cages varies between 40 and $120 \mathrm{~m}$, and there is a clear temperature and salinity gradient with depth (Oppedal et al., 2007), typical of fjords in this area. General information about stocking dates, duration, smolt size at stocking, number of net replacements are given in Table 1, while more specific details are given below:

\subsection{Cage 1}

$5 \times 5 \mathrm{~m}$ ( $7 \mathrm{~m}$ deep) net pen stocked on 16 August 2012, with 1000 diploid PIT tagged Atlantic salmon (average smolt weight as of 14-20 March 2012;62 g). The half mask mesh size (knot to knot, hereafter termed mesh size) at stocking was $15.5 \mathrm{~mm}$. The net pen was replaced with a clean net $(15.5 \mathrm{~mm}$ mesh size) late September 2012. In April 2013, the $15.5 \mathrm{~mm}$ mesh size net pen was replaced with a clean $22.5 \mathrm{~mm}$ mesh size net pen. Thereafter, the net pen was replaced with a clean $22.5 \mathrm{~mm}$ mesh size net pen on a regular basis in June, July, August, and September in 2013. On 26 September 2013, the 788 fish inside the net were species identified and measured for fork length and body weight.

\subsection{Cage 2}

Initially, two $5 \times 5 \mathrm{~m}$ ( $7 \mathrm{~m}$ deep $)$ net pens were stocked on 30 May 2013, with 1200 diploid PIT tagged Atlantic salmon per net pen (average smolt weight as of 5-8 March 2013; $105 \mathrm{~g}$ ). The mesh size at stocking was $15.5 \mathrm{~mm}$. The net pens were replaced with clean nets $(15.5 \mathrm{~mm}$ mesh size) in June, July, and August 2013. Then in September 2013, the $15.5 \mathrm{~mm}$ mesh size net pens were replaced with clean $22.5 \mathrm{~mm}$ mesh size net pens. In the period September 2013 to September 2014, the net pens were replaced with clean $22.5 \mathrm{~mm}$ mesh size net pens in April, June, July and August. The two replicate $5 \times 5 \mathrm{~m}$ net pens were merged into a $12 \times 12 \mathrm{~m}(15 \mathrm{~m}$ deep $)$ net 
P.G. Fjelldal et al.: Aquat. Living Resour. 2018, 31, 31

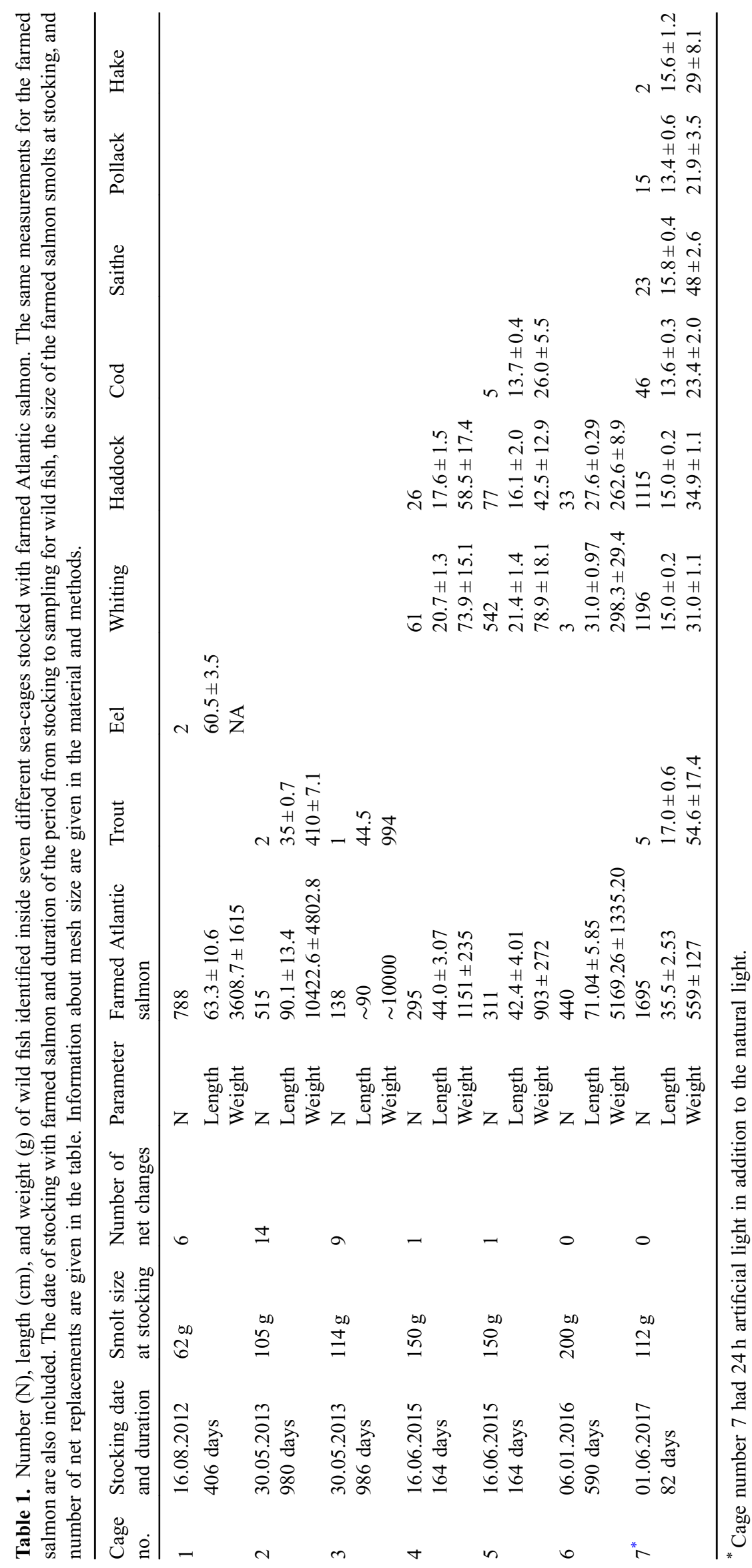


pen in September 2014 (immature individuals only, as mature individuals were transferred to freshwater consecutively each autumn). In the period September 2014 to February 2016, the $12 \times 12 \mathrm{~m} 22.5 \mathrm{~mm}$ mesh size net pen was replaced with an equal clean net pen on a regular basis in April, June, July, August, and September. On 4-5 February 2016, 500 adult immature fish were transferred from the net pen to land-based salt water tanks, and non-experimental fish were at this point identified and sampled. Experimental fish were not sampled at this point, thus their fork length and body length as of the last measurement on 14 September 2015 is presented in Table 1.

\subsection{Cage 3}

$5 \times 5 \mathrm{~m}$ (7 m deep) net pen stocked on 30 May 2013, with 300 diploid PIT tagged Atlantic salmon (average smolt weight as of 5-8 March $2013 ; 114 \mathrm{~g}$ ). The mesh size at stocking was $15.5 \mathrm{~mm}$. The net pen was replaced by an equal clean net pen in June, July, and August 2013. In September 2013, the $15.5 \mathrm{~mm}$ mesh size net pen was replaced with a clean $22.5 \mathrm{~mm}$ mesh size net pen. Thereafter, in the period September 2013 to February 2015 , the $22.5 \mathrm{~mm}$ mesh size net pen was replaced by an equal net pen on a regular basis in April, June, July, August, and September. On 10 February 2016, 138 adult fish were transferred from the net pen to salt water tanks on land, and non-experimental fish were at this point identified and sampled. The experimental fish were not sampled on a regular basis, however, as they were siblings of the fish in cage 2 , and they were expected to display similar growth measurements.

\subsection{Cage 4}

$5 \times 5 \mathrm{~m}$ ( $7 \mathrm{~m}$ deep) net pen stocked on 16 June 2015 with 295 diploid Atlantic salmon $(150 \mathrm{~g})$. The mesh size at stocking was $15.5 \mathrm{~mm}$. The net was replaced with a clean $22.5 \mathrm{~mm}$ mesh size net on 20 August 2015. On 27 November 2015, the fish inside the net were species identified and measured for fork length and body weight.

\subsection{Cage 5}

$5 \times 5 \mathrm{~m}$ ( $7 \mathrm{~m}$ deep) net pen stocked on 16 June 2015 with 311 triploid Atlantic salmon (150 g). The mesh size at stocking was $15.5 \mathrm{~mm}$. The net was replaced with a clean $22.5 \mathrm{~mm}$ mesh size net on 20 August. On 27 November 2015, the fish inside the net were species identified and measured for fork length and body weight.

\subsection{Cage 6}

$5 \times 5 \mathrm{~m}$ (14 m deep) pen stocked on 6 January 2016 with 440 diploid Atlantic salmon ( $200 \mathrm{~g})$. The very same net with mesh size $15.5 \mathrm{~mm}$ was used throughout the production. On 18 August 2017, the fish inside the net were species identified and measured for fork length and body weight.

\subsection{Cage 7}

$12 \times 12 \mathrm{~m}$ (15 m deep) pen stocked on 1 June 2017 with 1695 diploid salmon average smolt weight as of 10 May 2017; $112 \mathrm{~g}$ ). The mesh size at stocking was $15.5 \mathrm{~cm}$. The net pen was not changed during the study period; it was coated with antifouling paint. On 22 August 2017, the fish inside the net were species identified and measured for fork length and body weight.

In all of the above-described cages, the farmed salmon were fed a commercial salmon feed, with increasing pellet sizes according fish size. All cages at Smørdalen (cages 1-6) were operated with natural daylight for this latitude, while the cage at Solheim (cage 7) had an additional artificial light source at $7 \mathrm{~m}$ depth throughout the study period. The light source was a submersible lamp (Idema Aqua A/S, N-1344 Haslum) with a $400 \mathrm{~W}$ lamp bulb (Powerstar, HQI-BT 400W/ D Colour temperature: 32000 lumen, Osram, Lysaker, Norway), and was lit $24 \mathrm{~h}$ per day. With the exception of cage 6 that was manually cleaned by power washing, and cage 7 that was treated with antifouling paint, all nets were replaced on regular basis to avoid fouling. During the replacement of nets, it was not possible for the farmed fish to escape or wild fish to become trapped. The net replacement was done as follows: (i) the old and new nets were mounted side by side; (ii) $1 / 4$ of the top lining (one side) of the old and new nets were sewed tightly together and fused by a thin rope; (iii) the mid portion of the fused area was submerged allowing the fish to swim from the old to the new net; (iv) the netting in the old net was hauled in order to decrease the space inside the net, making all fish swim into the new net. All nets were checked for damage or holes before and after use. No holes were detected.

\section{Results and discussion}

This is the first report of wild fish trapped inside aquaculture sea-cages in Norway, the worlds largest producer of farmed Atlantic salmon. Based upon total inspection of seven sea-cages containing farmed Atlantic salmon, where marine fish had been observed, we identified varying numbers of wild sea trout (Salmo trutta L.), European eel (Anguilla anguilla), whiting (Merlangius merlangus), haddock (Melanogrammus aeglefinus), Atlantic cod (Gadus morhua), saithe (Pollachius virens), pollack (Pollachius pollachius), and hake (Merluccius merluccius) (Tab. 1). Supplementary file 1 shows an underwater film of the large shoals of wild fish trapped inside cage 7 .

Stomach contents were studied in 3 randomly sampled haddock in cage 6 , and all three had pellets in their stomachs. All sea trout were genotyped using a panel of 18 microsatellite markers developed for Atlantic salmon according to the established method (Glover et al., 2015), to exclude the remote possibility that they were salmon (data not shown). The wild fish documented in all seven sea-cages were all too big to pass through the meshes at the time of sampling. Therefore, we conclude that they swam into the sea-cages at some stage during the production cycle, out-grew the mesh-size, and ultimately became trapped within the sea-cage. Whether these wild fish repeatedly swam in and out of the sea-cages at a smaller size, before finally becoming trapped, is not known.

The sea-cages investigated are located in the inner end of a Norwegian fjord, a spawning area for several different marine species. Although gadoids such as Atlantic cod, whiting and haddock are demersal, 0-group fish live in the upper water 
layers $(\leq 40 \mathrm{~m})$ for a period of a few months before migrating to the seabed (Daan et al., 1990; Bjorke and Saetre, 1994). During this pelagic phase, juveniles may come in contact with, and indeed be attracted to, floating structures including seacages on commercial fish farms. 0-group gadoids, especially whiting and haddock, may find shelter under jellyfish (Hay et al., 1990) during this pelagic phase of their life-cycle. For whiting, Lynam and Brierley (2007) found a positive correlation between whiting 0-group residual survival and Cyanea spp. abundance. With their natural attraction to larger objects, 0 -group gadoids may be attracted to sea-cages during a certain period of their life cycle. In the cages that we sampled in the present study, whiting and haddock were the dominant species, which could reflect a high abundance of these two species in the study area. However, Salvanes and Nordeide (1993) in their study on the fish fauna in the sublittoral habitat in Masfjorden between 1985 and 1987, reported totals of 3287 saithe, 1582 pollock, 989 cod, 66 whiting, 55 haddock, and 8 hake caught in gillnets. Although the relative abundance of these species in Masfjorden has not been studied in more recent years, and coastal cod catches in Norway have strongly declined (Aglen et al., 2016), the high number of whiting and haddock in our study could indicate that these species are more attracted to the sea-cages.

Larval and juvenile marine fish may enter sea-cages to seek food, such as zooplankton. For instance, blooms of jellyfish may induce behavioral changes in some zooplankton (Carr and Pitt, 2008). Jellyfish are big zooplankton consumers (Möller, 1980; Purcell, 1992; Båmstedt et al., 1994; Barz and Hirche, 2007), that are too large to enter aquaculture sea-cages. Moreover, the water body closest to the large masses of farmed fish are rich in nutrients, and a highly productive area for low trophic levels, facilitating high abundance of both phyto- and zooplankton. Indeed, coastal fish farms may act as settlement sites for juvenile marine fish in the Mediterranean Sea, where copepods were found to be the main prey (Fernandez-Jover et al., 2009). Furthermore, it has been previously documented that aggregations of adult wild fish are found in association aquaculture seacages (e.g. Deudero et al., 1999; Bacher et al., 2015). For example, aggregations of wild fish have been reported immediately outside sea-cages on farms containing gilthead sea bream (Sparus aurata L.) and European seabass (Dicentrarchus labrax) in both the Mediterranean Sea (Dempster et al., 2002) and the Canary Islands (Tuya et al., 2006), and around Atlantic salmon farms in the NE Atlantic (Dempster et al., 2004, 2009, 2010, 2011; Skilbrei and Otterå, 2016; Otterå and Skilbrei, 2014). Several reasons for aggregations of marine fish around sea-cages have been suggested, among them an increased food supply and shelter from predators (Deudero et al., 1999). In addition, Dempster et al. (2011) investigated whether sea-cages could act as ecological traps (Battin, 2004) for wild gadoids, by attracting them and making them mistakenly prefer to stay in a potential low-quality area. However, based upon increased condition-factor and possibly higher reproductive output of the fish aggregated around sea-cages, they concluded that marine farms could contribute to increased productivity of wild populations.

The use of artificial light in sea-cage aquaculture may further impact on behavior of zooplankton and marine fish larvae. Most marine fish larvae are obligate visual feeders/ hunters (Blaxter, 1986). Cod larvae have a positive phototactic response (Nicolaisen and Bolla, 2016), and the copepod
Calanus finmarchicus shows a phototactic response depending on the sex and life stage (Miljeteig et al., 2014). Artificial light is commonly used in salmon aquaculture to support growth and suppress sexual maturation in sea cages (e.g. Hansen et al., 1992). A typical period which includes $24 \mathrm{~h}$ artificial light, with submerged lights hanging in the center of the cages, is from mid-January to the summer solstice (Oppedal et al., 1997). This period with $24 \mathrm{~h}$ artificial light lies within the hatching and larvae/juvenile period of many marine fish species. In the present context, however, only cage 7 was exposed to artificial $24 \mathrm{~h} \mathrm{light}$. Although this cage was the one with highest abundance of wild gadoids, no conclusion on the impact of artificial light can be drawn based on this single cage.

Some of the factors that attracted the wild marine fish to enter the sea-cages may also have attracted the trapped sea trout documented here. Furthermore, the observation of sea trout inside salmon sea-cages indicates that wild salmon smolts could also enter sea-cages. Eels on the other hand, are probably more attracted by dead fish and/or uneaten food at the bottom of the sea-cages.

Although marine fish larvae may display high survival rates in the absence of predation (Øiestad, 1985), gadoids were often absent in cages that held large salmon (Tab. 1). At the IMR's coastal farm in Austevoll, gadoids are rarely found in cages with larger salmon, but in a study with snorkel cages (Oppedal et al., 2017), several thousand juvenile gadoids were found inside a volume of the cage that was not accessible for the salmon (J.E. Fosseidengen, personal communication). Farmed Atlantic salmon are normally constantly fed pellets to satiation, but periods of hunger unintentionally caused by under-feeding or failure to the feeding system may impact on their feeding behavior. The possibility that the lack of observations of juvenile gadoids in cages containing larger salmon may thus be due to predation, but such behavior has yet to be documented. However, notice, in the present cages with larger salmon, the absence of wild gadoids in the cages were the nets were frequently replaced (cages 1,2,3) and presence of wild gadoids in the cage (cage 6) that was manually cleaned by power washing and not replaced. How replacement of nets, and change in mesh size, affects trapped wild fish, and if farmed salmon may prey on trapped marine fish larvae needs to be further studied.

In conclusion, the present study is the first to provide unequivocal evidence for the entrapment of wild marine fish in Norwegian salmon sea-cages. While it was not the aim of this study to quantify the frequency of this occurrence, and the ecological significance of these observations remains unclear, the diverse set of species and large numbers of individuals trapped in these cages suggests that the effect has potential significance. Given the fact that cage-based marine aquaculture is expanding throughout the world, this represents a topic clearly in need of systematic investigation. The regulations currently in operation in Canada, whereby fish farmers are required to report incidental catch in sea-cages, could be implemented in other regions to investigate further.

\section{Supplementary Material}

The Supplementary Material is available at https://www. alrjournal.org/10.1051/alr/2018020/olm. 


\section{References}

Aglen A, Nedreaas K, Moland E, Knutsen H, Kleiven AR, Johannessen T, Wehde H, Jørgensen T, Espeland SH, Olsen EM, Knutsen JA. 2016. Status of the cod along the coast in southern Norway (Svenskegrensa - Stadt). Fisken og Havet nr 4, ISSN 1894-5031, p. 55.

Bacher K, Gordoa A, Sagué O. 2015. Feeding activity strongly affects the variability of wild fish aggregations within fish farms: a sea bream farm as a case study. Aquac Res 46: 552-564.

Barz K, Hirche HJ. 2007. Abundance, distribution and prey composition of scyphomedusae in the southern North Sea. Mar Biol 151: 1021-1033.

Battin J. 2004. When good animals love bad habitats: ecological traps and the conservation of animal populations. Conserv Biol 18: 1482-1491.

Blaxter JHS. 1986. Development of sense-organs and behavior of teleost larvae with special reference to feeding and predator avoidance. Trans Am Fish Soc 115: 98-114.

Bjorke H, Saetre R. 1994. Transport of larvae and juvenile fish into central and northern Norwegian waters. Fish Oceanogr 3: 106-119.

Båmstedt U, Martinussen MB, Matsakis S. 1994. Trophodynamics of the two scyphozoan jellyfishes, Aurelia aurita and Cyanea capillata, in western Norway. ICES J Mar Sci 51: 369-382.

Carr EF, Pitt KA. 2008. Behavioural responses of zooplankton to the presence of predatory jellyfish. J Exp Mar Biol Ecol 354: 101-110.

Daan N, Bromley PJ, Hislop JRG, Nielsen NA. 1990. Ecology of North Sea Fish. Neth J Sea Res 26: 343-386.

Dempster T, Sanchez-Jerez P, Bayle-Sempere JT, Gimenez-Casalduero F, Valle C. 2002. Attraction of wild fish to sea-cage fish farms in the south-western Mediterranean Sea: spatial and shortterm temporal variability. Mar Ecol Prog Ser 242: 237-252.

Dempster T, Sanchez-Jerez P, Bayle-Sempere J, Kingsford M. 2004. Extensive aggregations of wild fish at coastal sea-cage fish farms. Hydrobiologia 525: 245-248.

Dempster T, Uglem I, Sanchez-Jerez P, Fernandez-Jover D, BayleSempere J, Nilsen R, Bjorn PA. 2009. Coastal salmon farms attract large and persistent aggregations of wild fish: an ecosystem effect. Mar Ecol Prog Ser 385: 1-14.

Dempster T, Sanchez-Jerez P, Uglem I, Bjorn PA. 2010. Speciesspecific patterns of aggregation of wild fish around fish farms. Est Coast Shelf Sci 86: 271-275.

Dempster T, Sanchez-Jerez P, Fernandez-Jover D, Bayle-Sempere J, Nilsen R, Bjørn PA, Uglem I. 2011. Proxy measures of fitness suggests coastal fish farms can act as population sources and not ecological traps for wild gadoid fish. PLOS ONE 6: e15646. DOI:10.1371/journal.pone.0015646

Deudero S, Merella P, Morales-Nin B, Massutí E, Alemany F. 1999. Fish communities associated with FADs. Sci Mar 63: 199-207.

Fernandez-Jover D, Sanchez-Jerez P, Bayle-Sempere JT, ArechavalaLopez P, Martinez-Rubio L, Jimenez JAL, Lopez FJM. 2009. Coastal fish farms are settlement sites for juvenile fish. Mar Environ Res 68: 89-96.

Forseth T, Barlaup BT, Finstad B, Fiske P, Gjoaester H, Falkegard M, Hindar A, Mo TA, Rikardsen AH, Thorstad EB, Vollestad LA, Wennevik V. 2017. The major threats to Atlantic salmon in Norway. ICES J Mar Sci 74: 1496-1513.

Glover KA, Madhun AS, Dahle G, Sorvik AGE, Wennevik V, Skaala O, Morton HC, Hansen TJ, Fjelldal PG. 2015. The frequency of spontaneous triploidy in farmed Atlantic salmon produced in Norway during the period 2007-2014. BMC Genetics 16. DOI:10.1186/s12863-015-0193-0
Glover KA, Solberg MF, McGinnity P, Hindar K, Verspoor E, Coulson MW, Hansen MM,Araki H, Skaala Ø, Svåsand T. 2017. Half a century of genetic interaction between farmed and wild Atlantic salmon: status of knowledge and unanswered questions. Fish Fish 18: 890-927.

Hansen T, Stefansson SO, Taranger GL. 1992. Growth and sexual maturation in Atlantic salmon, Salmo salar L., reared in seacages at two different light regimes. Aquac Fish Man 23: 275-280.

Hay SJ, Hislop JRG, Shanks AM. 1990. North-Sea scyphomedusaesummer distribution, estimated biomass and significance particularly for 0-group gadoid fish. Neth J Sea Res 25: 113-130.

Lynam CP, Brierley AS. 2007. Enhanced survival of 0-group gadoid fish under jellyfish. Mar Biol 150: 1397-1401.

Miljeteig C, Olsen AJ, Barnes AS, Altin D, Nordtug T, Alver MO, Speed JDM, Munro Jenssen B. 2014. Sex and life stage dependent phototactic response of the marine copepod Calanus finmarchicus (Copepoda: Calanoida). J Exp Mar Biol Ecol 451: 16-24.

Möller H. 1980. Scyphomedusae as predators and food competitors of larval fish. Meeresforschung 28: 90-100.

Nicolaisen O, Bolla S. 2016. Behavioural responses to visual environment in early stage Atlantic cod Gadus morhua L. larvae. Aquac Res 47: 189-198.

Oppedal F, Taranger GL, Juell JE, Fosseidengen JE, Hansen T. 1997. Light intensity affects growth and sexual maturation of Atlantic salmon (Salmo salar) postsmolts in sea cages. Aquat Living Resour 10: 351-357.

Oppedal F, Juell JE, Johansson D. 2007. Thermo- and photoregulatory swimming behaviour of caged Atlantic salmon: implications for photoperiod management and fish welfare. Aquaculture 265: 70-81.

Oppedal F, Samsing F, Dempster T, Wright DW, Bui S, Stien LH. 2017. Sea lice infestation levels decrease with deeper 'snorkel' barriers in Atlantic salmon sea-cages. Pest Manag Sci 10.1002/ps.4560

Otterå H, Skilbrei OT. 2014. Possible influence of salmon farming on long-term resident behaviour of wild saithe (Pollachius virens L.). ICES J Mar Sci 71: 2484-2493.

Purcell JE. 1992. Effects of predation by the scyphomedusan Chrysaora quinquecirrha on zooplankton populations in Chesapeake Bay, USA. Mar Ecol Prog Ser 87: 65-76.

Salvanes AGV, Nordeide JT. 1993. Dominating sublittoral fish species in a west Norwegian fjord and their trophic links to cod (Gadus morhua L.). Sarsia 78: 221-234.

Sanchez-Jerez P, Fernandez-Jover D, Bayle-Sempere J, Valle C, Dempster T, Tuya F, Juanes F. 2008. Interactions between bluefish Pomatomus saltatrix (L.) and coastal sea-cage farms in the Mediterranean Sea. Aquaculture 228: 61-67.

Skilbrei OT, Otterå H. 2016. Vertical distribution of saithe (Pollachius virens) aggregating around fish farms. ICES J Mar Sci 73: 11861195.

Taranger GL, Karlsen Ø, Bannister RJ, Glover KA, Husa V, Karlsbakk E, Kvamme BO, Boxaspen KK, Bjorn PA, Finstad B, Madhun AS, Morton HC, Svasand T. 2015. Risk assessment of the environmental impact of Norwegian Atlantic salmon farming. ICES J Mar Sci 72: 997-1021.

Tuya F, Sanchez-Jerez P, Dempster T, Boyra A, Haroun RJ. 2006. Changes in demersal wild fish aggregations beneath a sea-cage fish farm after the cessation of farming. J Fish Biol 69: 682-697.

Øiestad V. 1985. Predation of fish larvae as a regulatory force, illustrated in mesocosm studies with large groups of larvae. $N A F O$ Sci Coun Stud 8: 25-32.

Cite this article as: Fjelldal PG, Solberg MF, Glover KA, Folkedal O, Nilsson J, Finn RN, Hansen TJ. 2018. Documentation of multiple species of marine fish trapped in Atlantic salmon sea-cages in Norway. Aquat. Living Resour. 31: 31 